\title{
PENGARUH KOMPETENSI DAN LINGKUNGAN KERJA TERHADAP MOTIVASI SERTA KINERJA PEGAWAI NEGERI SIPIL DI DINAS TANAMAN PANGAN HORTIKULTURA DAN PERKEBUNAN PROVINSI RIAU
}

\author{
Ditta Amelia ${ }^{1}$, B. Isyandi ${ }^{2}$, Raden Lestari Garnasih ${ }^{3}$ \\ ${ }^{123}$ Pasca Sarjana Magister Manajemen Universitas Riau
}

\begin{abstract}
Abstrak
Tujuan dari penelitian ini adalah untuk mengukur pengaruh kompetensi dan lingkungan kerja terhadap motivasi dan kinerja karyawan. Hasil penelitian ini diharapkan dapat memberikan manfaat bagi instansi terkait dan bidang keilmuan lainnya. Sampel penelitian ini adalah 170 pegawai yang merupakan PNS. Teknik pengambilan sampel menggunakan rumus Slovin yang dikombinasikan dengan stratisfied sampling sehingga setiap kelas karyawan mendapatkan kesempatan yang sama untuk dijadikan objek penelitian. Pengumpulan data dilakukan dengan metode kuesioner dan wawancara. Teknik analisis data yang digunakan dalam penelitian ini adalah analisis jalur. Hasil penelitian menunjukkan bahwa motivasi, kompetensi, dan lingkungan kerja berpengaruh terhadap kinerja. Kompetensi dan lingkungan kerja tidak secara tidak langsung mempengaruhi kinerja melalui motivasi. Lebih lanjut ditemukan bahwa motivasi tidak dapat memediasi kompetensi dan lingkungan kerja terhadap kinerja. Pejabat hendaknya meningkatkan apresiasi terhadap prestasi karyawan, meningkatkan kuantitas dan kualitas pendidikan dan pelatihan, meningkatkan kolaborasi antara karyawan dan pimpinan, meningkatkan ketepatan waktu, dan membangun hubungan yang erat antara pimpinan dan karyawan.
\end{abstract}

Kata kunci: Kompetensi, lingkungan kerja, motivasi, kirnerja

\section{EFFECT OF COMPETENCE AND WORK ENVIRONMENT MOTIVATION AND PERFORMANCE OF CIVIL SERVANTS IN THE DEPARTMENT OF HORTICULTURE CROPS AND OIL RIAU PROVINCE}

\begin{abstract}
The purpose of this study is to measure the effects of competence and work environment on motivation and performance of the employees. The result of this study is expected to provide benefits to the relevant instance and other scientific fields. The samples of this study are 170 employees which are civil servants. The was processed using the Slovin formula combined with stratisfied sampling as the sampling technique so that each class of employees get the same opportunity to be used as research object.The data was collected using questionnaires and interviews methiods. The data analysis technique used for this study is path analysis. The results show that motivation, competence, and work environment affect performance. Competency and work environment do not indirectly influence performance through motivation. Further it is found that motivation cannot mediate competency and work environment on performance. Official should increase the appreciation of the employees' achievements, increase the quantity and quality of education and training, increase collaboration between employees and leaders, improve timeliness, and build close relationships between leaders and employees
\end{abstract}

Keywords:Competence, work environment, motivation, performance 


\section{PENDAHULUAN}

Lingkungan kerja Dinas Tanaman Pangan Hortikultura dan Perkebunan Provinsi Riau masih belum memadai dalam menciptakan suasana yang nyaman bagi pegawai. Pendingin ruangan yang tidak berfungsi baik, sarana prasarana yang kurang memadai, serta penerangan yang kurang baik menjadi keluhan pegawai Dinas Tanaman Pangan Hortikultura dan Perkebunan Provinsi Riau. Organisasi harus mengusahakan agar pegawainya dapat berpandangan positif terhadap lingkungan kerjanya, karena lingkungan kerja sangat berpengaruh pada pekerjaan yang dilakukan. Lingkungan kerja yang kondusif dan menyenangkan akan menimbulkan perasaan nyaman dan puas pada pegawai sehingga menunjang kinerja pegawai.

Kondisi lingkungan kerja yang baik berpengaruh dalam meningkatkan kinerja pegawai karena berperan penting dalam mengurangi rasa cepat lelah serta menghilangkan atau mengurangi rasa bosan sehingga semangat kerja meningkat, betah berada di tempat kerja, dan bertanggung jawab dalam melaksanakan tugasnya. Begitu juga dengan lingkungan non fisik yang baik, seperti terpenuhinya kebutuhan pegawai, pedoman kerja yang jelas, hubungan yang harmonis antar pegawai dengan rekan kerja dan atasannya, dapat menimbulkan rasa nyaman pada pegawai sehingga motivasinya meningkat.

Dapat dikatakan bahwa dalam meningkatkan kinerja pegawainya suatu organisasi perlu untuk memperhatikan kompetensi pegawai yang sesuai dengan bidangnya, menciptakan lingkungan kerja yang kondusif dan pemberian motivasi. Melalui proses-proses tersebut, pegawai diharapkan akan lebih memaksimalkan tanggung jawab atas pekerjaan mereka.

Dinas Tanaman Pangan Hortikultura dan Perkebunan Provinsi Riau mempunyai tugas melaksanakan urusan Pemerintahan Daerah di Bidang pertanian sesuai dengan asas Desentralisasi, Dekonsentrasi dan Tugas Pembantuan. Dinas Tanaman Pangan Hortikultura dan Perkebunan bertanggung jawab untuk melaksanakan pembinaan, koordinasi, pengendalian, pemantauan dan evaluasi kegiatan peningkatan produksi dan pengembangan pertanian .

Dinas Tanaman Pangan, Hortikultura dan Perkebunan Provinsi Riau sebagai lembaga pemerintahan tidak bisa dipisahkan dari sistem perekonomian demi tercapainya tujuan Negara dalam mencapai tujuan dalam bidang pertanian dan pemenuhan pangan. Oleh karena itu peningkatan kinerja pegawai sangat dibutuhkan. Dinas Tanaman Pangan Hortikultura dan Perkebunan Provinsi Riau sendiri memiliki visi "Terwujudnya Pertanian Riau yang Maju, Berdaya Saing tinggi dan Berkelanjutan Menuju Petani dan Peternak yang Sejahtera dengan Dukungan Aparatur yang Andal" (Distanak.riau.go.id).

Sumber daya manusia mempunyai peranan yang sangat penting dalam suatu organisasi. Dalam perkembangan era informasi sekarang ini, setiap organisasi baik itu sosial maupun organisasi bisnis akan selalu dihadapkan pada permasalahan sumber daya manusia. Keterkaitan sumber daya manusia dengan peradaban era informasi sangat penting, sehingga dalam pengelolaan sumber daya manusia terdapat kecenderungan perhatian yang semakin membesar terhadap manusia sebagai faktor penentu keberhasilan organisasi. Perhatian itu bukan hanya 
tertuju pada manusia sebagai individu, melainkan juga pada manusia dalam kelompok organisasi.

Dari aspek kuantitas, potensi sumber daya manusia Indonesia relatif sangat besar mengingat jumlah penduduknya sangat banyak. Namun dari aspek kualitas, Indonesia masih mengalami kekurangan tenaga kerja (SDM) yang berkualitas sesuai dengan tuntutan jabatan dan profesi pekerjaan. Dalam mengisi otonomi daerah, peningkatan kualitas SDM mutlak diperlukan demi mencapai tujuan Negara. Organisasi yang akan sukses adalah organisasi yang mengerti dan mengetahui bagaimana pentingnya dan upaya-upaya apa saja yang harus dilakukan untuk melaksanakan strategi pengembangan sumber daya manusia dalam organisasinya. Dengan demikian peran sumber daya manusia dalam organisasi sangatlah penting dan sangat berpengaruh besar terhadap jalannya atau lancarnya kegiatan suatu organisasi dalam mencapai tujuannya.

Sebagai salah satu bagian pemerintahan negara Indonesia, Pemerintah Provinsi Riau terus berupaya dalam memaksimalkan pelayanan terhadap masyarakat. Berbagai sektor pembangunan dan pengembangan daerah juga menjadi hal yang penting untuk diperhatikan demi mencapai tujuan secara keseluruhan. Dengan tingginya kinerja aparatur pemerintahan di Provinsi Riau maka akan memberikan dampak terhadap baiknya tata pengelolaan pemerintah. Peningkatan hasil pertanian merupakan upaya untuk mewujudkan kebijakan umum pembangunan pertanian Kota Pekanbaru, yaitu mengembangkan pertanian yang mampu menghasilkan produk-produk tanaman pangan yang dapat memberi nilai tambah dan memperluas kesempatan kerja.

Berdasarkan data dari badan pusat statistik pekanbaru pada.bps.go.id angka sementara hasil pencacahan lengkap Sensus Pertanian 2013, jumlah rumah tangga usaha pertanian di Kota Pekanbaru mengalami penurunan sebanyak 8.025 rumah tangga dari 19.324 rumah tangga pada tahun 2003 menjadi 11.299 rumah tangga pada tahun 2013, yang berarti menurun sebesar 41,53 persen selama sepuluh tahun. Jumlah perusahaan pertanian berbadan hukum selama sepuluh tahun terakhir tidak banyak berubah.

Hal ini menunjukkan bahwa pemerintah daerah harus lebih memperhatikan sektor pertanian di Provinsi Riau demi mendukung terpenuhinya kebutuhan masyarakat dan pengembangan serta pembangunan daerah yang lebih baik. Dalam penjelasan umum Undangundang nomor 5 tahun 2014 dinyatakan bahwa dalam rangka pelaksanaan cita-cita bangsa dan mewujudkan tujuan negara sebagaimana tercantum dalam pembukaan Undang-Undang Dasar Negara Republik Indonesia Tahun 1945, perlu dibangun aparatur sipil negara yang memiliki integritas, profesional, netral dan bebas dari intervensi politik, bersih dari praktik korupsi, kolusi, dan nepotisme, serta mampu menyelenggarakan pelayanan publik bagi masyarakat dan mampu menjalankan peran sebagai unsur perekat persatuan dan kesatuan bangsa berdasarkan Pancasila dan Undang-Undang Dasar Negara Republik Indonesia Tahun 1945.

Sumber daya manusia merupakan salah satu aset penting yang dimiliki oleh setiap organisasi yang dikelola dan dimanfaatkan bersama dengan sumber daya lainnya untuk pencapaian tujuan organisasi. Sumber daya manusia sebagai subjek dan tujuan dari manajemen sumber daya manusia harus dapat menjalankan fungsinya sebaik mungkin agar dapat tercapainya tujuan organisasi. Sumber daya manusia merupakan aset organisasi yang paling penting, dan membuat sumberdaya organisasi lainnya menjadi bekerja. Dengan demikian, 
tanpa sumberdaya manusia sumber daya lainnya akan menganggur dan kurang bermanfaat dalam mencapai tujuan organisasi.

Untuk mencapai tujuan organisasi, tentunya setiap pegawai dituntut untuk memaksimalkan kinerja yang dia miliki. Kinerja karyawan adalah hal yang penting untuk diperhatikan organisasi, karena dapat mempengaruhi tercapainya tujuan dan kemajuan organisasi dalam suatu persaingan global yang sering berubah. Kinerja merupakan suatu kegiatan dan menyempurnakannya sesuai dengan tanggung jawabnya dengan hasil seperti yang di harapkan. Kinerja yang baik dapat dilihat dari hasil yang di dapat, sesuai dengan standar organisasi.

Terdapat faktor-faktor negatif yang dapat menurunkan kinerja pegawai, diantaranya adalah menurunnya keinginan pegawai untuk mencapai prestasi kerja, kurangnya ketepatan waktu dalam penyelesaian pekerjaan sehingga kurang menaati peraturan, pengaruh yang berasal dari lingkungannya, teman sekerja yang juga menurun semangatnya dan tidak adanya contoh yang harus dijadikan acuan dalam pencapaian prestasi kerja yang baik.

Kinerja yang baik memerlukan kemampuan intelektual dan fisik yang sesuai dengan pekerjaan seseorang. Seorang karyawan agar memiliki kinerja yang baik, maka diperlukan kemampuan pengetahuan tentang bidang tugasnya, seperti pengetahuan yang mendalam tentang materi pekerjaannya, teknik pelaksanaan pekerjaan, cara berkomunikasi dalam proses pelayanan, interaksi antar unitnya, dan lain sebagainya. Untuk kemampuan fisik, seperti tidak cacat fisik yang dapat menjadi penghalang/kendala dalam bertugas. Seseorang karyawan yang memiliki kemampuan kurang dari yang dipersyaratkan akan besar kemungkinannya untuk gagal. Jika sebaliknya, yaitu memiliki kemampuan lebih tinggi dari yang dipersyaratkan, maka akan menjadi tidak efisien di dalam organisasi dan bahkan dapat berakibat kurang puas kerja atau dapat pula menimbulkan stress/frustrasi, dan sebagainya. Kebutuhan tenaga-tenaga terampil didalam berbagai bidang sudah merupakan tuntutan dunia global yang tidak dapat ditunda dan dituntut untuk memiliki kemampuan dalam membuat rencana pengembangan SDM yang berkualitas, dengan selalu melakukan perbaikan Ini artinya Instansi harus memperbaiki kinerja instansinya melalui perbaikan kinerja karyawannya.

Motivasi yang merupakan yang hadir dari internal maupun eksternal seorang individu juga merupakan faktor yang dapat meningkatkan kinerja, dengan tingginya motivasi dalam bekerja pada karyawan tentunya akan mampu meningkatkan output yang baik bagi organisasi.

Sumber daya manusia merupakan kekuatan penggerak organisasi. Berbagai literatur telah menuliskan bahwa motivasi mendorong munculnya perilaku. Motivasi ada karena adanya kebutuhan dalam individu yang harus dipenuhi. Sebagai intensi dari perilaku maka perilaku yang muncul sesuai dengan motivasi yang ada. Dengan demikian dapat dikatakan bahwa motivasi kerja sangat diperlukan untuk memunculkan perilaku bekerja yang positif. Terdapat keluhan dari pegawai mengenai minim nya penghargaan yang diberikan oleh Dinas Tanaman Pangan Hortikultura dan Perkebunan Provinsi Riau terhadap prestasi dan kinerja yang baik. Hal tersebut juga menyebabkan pegawai menjadi tidak berusaha memahami tanggung jawab dan tidak antusias untuk menjadi kreatif. 
Tantangan reformasi birokrasi meliputi area organisasi, regulasi, SDM, prosedur serta mindset dan culture set. Dalam area organisasi, masih terdapat ketidaksesuaian antara struktur dan fungsi organisasi. Dalam area SDM, terdapat banyak pegawai secara jumlah memadai, namun secara kualitas belum memadai, distribusi pegawai yang tidak merata, penempatan yang tidak sesuai dengan kompetensi, dan lain sebagainya (Buletin Badan Kepegawaian Negara ,2015).

Lingkungan kerja Dinas Tanaman Pangan Hortikultura dan Perkebunan Provinsi Riau masih belum memadai dalam menciptakan suasana yang nyaman bagi pegawai. Pendingin ruangan yang tidak berfungsi baik, sarana prasarana yang kurang memadai, serta penerangan yang kurang baik menjadi keluhan pegawai Dinas Tanaman Pangan Hortikultura dan Perkebunan Provinsi Riau. Organisasi harus mengusahakan agar pegawainya dapat berpandangan positif terhadap lingkungan kerjanya, karena lingkungan kerja sangat berpengaruh pada pekerjaan yang dilakukan. Lingkungan kerja yang kondusif dan menyenangkan akan menimbulkan perasaan nyaman dan puas pada pegawai sehingga menunjang kinerja pegawai.

Kondisi lingkungan kerja yang baik berpengaruh dalam meningkatkan kinerja pegawai karena berperan penting dalam mengurangi rasa cepat lelah serta menghilangkan atau mengurangi rasa bosan sehingga semangat kerja meningkat, betah berada di tempat kerja, dan bertanggung jawab dalam melaksanakan tugasnya. Begitu juga dengan lingkungan non fisik yang baik, seperti terpenuhinya kebutuhan pegawai, pedoman kerja yang jelas, hubungan yang harmonis antar pegawai dengan rekan kerja dan atasannya, dapat menimbulkan rasa nyaman pada pegawai sehingga motivasinya meningkat.

Dapat dikatakan bahwa dalam meningkatkan kinerja pegawainya suatu organisasi perlu untuk memperhatikan kompetensi pegawai yang sesuai dengan bidangnya, menciptakan lingkungan kerja yang kondusif dan pemberian motivasi. Melalui proses-proses tersebut, pegawai diharapkan akan lebih memaksimalkan tanggung jawab atas pekerjaan mereka.

Dinas Tanaman Pangan Hortikultura dan Perkebunan Provinsi Riau mempunyai tugas melaksanakan urusan Pemerintahan Daerah di Bidang pertanian sesuai dengan asas Desentralisasi, Dekonsentrasi dan Tugas Pembantuan. Dinas Tanaman Pangan Hortikultura dan Perkebunan bertanggung jawab untuk melaksanakan pembinaan, koordinasi, pengendalian, pemantauan dan evaluasi kegiatan peningkatan produksi dan pengembangan pertanian .

Dinas Tanaman Pangan, Hortikultura dan Perkebunan Provinsi Riau sebagai lembaga pemerintahan tidak bisa dipisahkan dari sistem perekonomian demi tercapainya tujuan Negara dalam mencapai tujuan dalam bidang pertanian dan pemenuhan pangan. Oleh karena itu peningkatan kinerja pegawai sangat dibutuhkan. Dinas Tanaman Pangan Hortikultura dan Perkebunan Provinsi Riau sendiri memiliki visi "Terwujudnya Pertanian Riau yang Maju, Berdaya Saing tinggi dan Berkelanjutan Menuju Petani dan Peternak yang Sejahtera dengan Dukungan Aparatur yang Andal” (Distanak.riau.go.id). 


\section{KAJIAN TEORI}

\section{Kinerja}

Manajemen sumber daya manusia sangat erat kaitannya dengan keunggulan organisasi. Keunggulan organisasi juga tidak bisa dipisahkan dari kinerja sunber daya manusia yang ada dalam suatu organisasi. Wether dan Davis dalam Isyandi (2018) menyatakan bahwa kinerja dapat digambarkan sebagai apa yang dapat dicapai atas prestasi yang dilihat, kemampuan kerja (alat), bekerja berkemampuan dan bertenanga. Sedarmayanti (2011) mengemukakan bahwa kinerja merupakan terjemahan dari performance yang berarti hasil kerja seorang pekerja, sebuah proses manajemen atau suatu organisasi secara keseluruhan, dimana hasil kerja tersebut harus dapat ditunjukkan buktinya secara konkrit dan dapat diukur (dibandingkan dengan standar yang telah ditentukan).

\section{Motivasi}

Manajemen sumber daya manusia tidak terlepas dari usaha dalam memberikan dorongan dan menggerakkan orang-orang agar bersedia bekerja semaksimal mungkin demi tercapainya tujuan sehingga perlu diusahakan adanya komunikasi dan peran serta dari semua pihak yang bersangkutan. Menurut Hasibuan dalam Isyandi (2017) Motivasi adalah mempersoalkan bagaimana cara mengarahkan daya dan potensi bawahan, agar mau bekerjasama secara produktif berhasil mencapai dan mewujudkan tuhuan yang telah ditentukan. Motivasi sangat penting karena motivasi adalaha hal yang menyebabkan, menyalurkan, dan mendukung perilaku manusia supaya mau bekerja giat dan antusias mencapai hasil yang optimal. Perusahaan bukan saja mengharapkan pegawai mampu, cakap, dan terampil tetapi juga mau bekerja giat dan berkeinginan mencapai hasil maksimal.

Motivasi adalah suatu faktor yag mendorong seseorang untuk melakukan suatu aktivitas tertentu (Sutrisno, 2011). Motivasi menjadi salah satu pondasi penting bagi tumbuhnya kinerja pegawai dalam sebuah organisasi. Bagaimanapun setiap pegawai akan terpacu untuk bekerja lebih keras jika memiliki dan atau terdapat motivasi di dalamnya. Bahkan kepuasan dari hasil pekerjaan dan bagi pegawai bersangkutan sangat tergantung dari peran pimpinan menumbuhkan motivasi.

Robbins dan Counter (Suwatno dan Donni, 2013) mengemukakan motivasi kerja sebagai kesediaan untuk melaksanakan upaya tinggi untuk memenuhio kebutuhan individual tertentu. Dari beberapa definisi di atas, dapat dismpulkan bahwa organisasi hanya akan berhasil mencapai tujuan dan berbagai sasarannya, apabila semua komponen organisasi berupaya menampilkan kinerja atau memiliki motivasi yang tinggi secara optimal.

\section{Kompetensi}

Kompetensi dikatakan sebagai salah satu faktor yang mempengaruhi kinerja. Kompetensi adalah karakteristik dasar yang dapat di hubungkan dengan peningkatan kinerja individu atau tim. Menurut Edison, dkk (2017) Kompetensi adalah kemampuan individu untuk melaksanakan suatu pekerjaan dengan benar dan memiliki keunggulan yang didasarkan pada 
hal-hal yang menyangkut pengetahuan, keahlian, dan sikap. Menurut George Klemp (dalam Edison, dkk, (2017) Kompetensi adalah karakteristik yang mendasari seseorang menghasilkan pekerjaan yang efektif dan atau kinerja yang unggul. Menurut Spencer and Spencer dalam Edison, dkk (2017) menambahkan bahwa " a competency is an underying characteristic of individual that is causally related to criterion referenced effective and or superior peformance in a job or situation". Artinya bahwa karakteristik yang mendasari individu yang berkaitan dengan hubungan kausal atau sebab akibat pelaksanaan yang efektif dan atau unggul dalam pekerjaan atau keadaan)

Sriwidodo dan Haryanto (2010) mengemukakan pendapatnya bahwa kinerja dan keefektifan pegawai dalam melaksanakan tugas sangat ditentukan oleh kompetensi yang disyaratkan oleh bidang pekerjaan. Kompetensi seseorang menjadi ciri dasar individu dikaitkan dengan standar kriteria kinerja yang efektif dan superior. Berkaitan dengan ungkapan di atas spencer dan spencer dalam Abdussamad (2011) membagi kompetensi dalam dua tingkatan yakni ada yang tampak dan yang tidak tampak, Spencer dan spencer mengilustrasikan seperti gunung es di mana ada yang tampak di permukaan, adapula yang tidak terlihat di permukaan.

Kompetensi yang tampak di pemukaan adalah Pengetahuan (Knowledge) dan Keterampilan (Skill), kompetensi yang tidak tampak di permukaan adalah Nilai-nilai(Srole), konsep diri (self image), karakteristik personal (traits), dan motif (motives). Kompetensi di temukan pada orang-orang yang di klasifikasikan sebagai berkinerja unggul atau efektif. Dari pengertian di atas dapat ditarik tegaskan bahwa kompetensi yaitu kemampuan seseorang berkinerja untuk melaksanakan pekerjaan dengan sukses serta menghasilkan prestasi kerja, dan kesuksesan suatu organisasi tergantung pada kombinasi kompetensi kepemimpinan yang efektif dan kompetensi tenaga kerjanya.

\section{Lingkungan Kerja}

Lingkungan kerja mempunyai pengaruh yang sangat besar terhadap pegawai dalam melaksanakan operasi perusahaan. Kondisi lingkungan kerja yang baik dan memadai, akan menunjang para pegawai menjadi senang dengan tempat kerjanya. Dengan adanya perasaan senang terhadap tempat kerjanya maka akan menimbulkan perasaan puas pada diri pegawai dan akan menimbulkan semangat kerja yang lebih baik sehingga tujuan-tujuan organisasi akan tercapai pula dengan baik.

Lingkungan kerja adalah tempat dimana pegawai melakukan aktivitas setiap harinya. Lingkungan kerja yang kondusif memberikan rasa aman dan memungkinkan pegawai untuk dapat bekerja optimal. Lingkungan kerja dapat mempengaruhi emosi pegawai. Jika pegawai menyenangi lingkungan kerja dimana dia bekerja, maka pegawai tersebut akan betah di tempat kerjanya, melakukan aktivitas sehingga waktu kerja dipergunakan secara efektif. Lingkungan kerja itu mencakup hubungan kerja yang terbentuk antara sesama pegawai dan hubungan kerja antara bawahan dan atasan serta lingkungan fisik tempat pegawai bekerja. 


\section{METODE PENELITIAN}

\section{Desain Penelitian}

Desain yang dipergunakan dalam ini penelitian kuantitatif. Dalam metoda ini teori ilmiah yang telah diterima kebenarannya dijadikan acuan dalam mencari kebenaran selanjutnya. Penelitian kuantitatif merupakan suatu proses menemukan pengetahuan yang menggunakan data berupa angka sebagai alat menganalisis keterangan mengenai apa yang ingin diketahui Penelitian ini akan dilakukan mulai bulan Mei 2019 sampai dengan bulan Juli 2020. Untuk mendapatkan data yang diperlukan dalam penulisan tesis ini, penulis mengadakan penelitian pada Dinas Tanaman Pangan Hortikultura dan Perkebunan Provinsi Riau di Kota Pekanbaru.

\section{Populasi dan Sampel}

Populasi adalah wilayah generalisasi yang terdiri atas objek atau subjek yang mempunyai kualitas dan karakteristik tertentu yang ditetapkan oleh peneliti untuk dipelajari dan kemudian ditarik kesimpulan.Populasi dari penelitian ini adalah seluruh karyawan Dinas Tanaman Pangan Hortikultura dan Perkebunan Pekanbaru yang berjumlah 385 orang. Apabila subjek penelitian lebih dari 100 orang, maka penelitian menggunakan rumus Slovin orang dapat diambil derajat ketidakpastian antara 5-10\% (Arikunto, 2011). Oleh karna itu yang dijadikan sampel adalah sebanyak 196 orang pegawai. Dengan teknik pengambilan sampel stratified sampling dan purposive sampling, dimana kita yang menentukan sendiri sampel yang di ambil, dengan rumus Slovin :

$$
\mathbf{N}=\frac{\mathrm{N}}{1+\mathrm{n}(\mathrm{e})^{2}}=\frac{335}{1+335(0,05)^{2}}=170
$$

Keterangan :

$\mathrm{N} \quad$ : Populasi

n : Ukuran Sampel

E :Tingkat kesalahan pengambilan sampel 5\% $(0,05)$

Sampel berdasarkan tingkat golongan pegawai mulai dari I sampai IV.

Tabel 1. Sampel

\begin{tabular}{llll}
\hline No. & Golongan & Jumlah & Sampel \\
\hline $\mathbf{1 .}$ & I & 4 & 2 \\
\hline $\mathbf{2 .}$ & II & 78 & 45 \\
\hline $\mathbf{3}$ & III & 212 & 102 \\
\hline $\mathbf{4}$ & IV & 41 & 25 \\
\hline & Jumlah & 335 Orang & 170 Orang
\end{tabular}

Sumber : $\overline{\text { Dinas Tanaman Pangan, Hortikultura dan Perkebunan Provinsi Riau (2018) }}$

Stratified sampling merupakan cara penarikan sampel untuk populasi yang memiliki karakteristik heterogen atau karakteristik yang dimiliki populasi bervariasi dengan tujuan agar setiap kelompok variasi mendapat kesempatan untuk diteliti. Jadi sampel penelitian telah terdiri dan mewakili dari masing-masing tingkatan kelompok yang ada. 


\section{Teknik Pengumpulan Data}

Teknik pengupulan data yang dipergunakan dalam penelitian ini adalah :

- Wawancara yaitu cara pengumpulan data yang penulis lakukan dengan melakukan interview pada tempat penelitian.

- Kuesioner yaitu pengumpulan data dengan cara menyusun pertanyaan yang diajukan kepada karyawan.

\section{Analisis Jalur (Path Analysis)}

Analisis jalur digunakan untuk menguji pengaruh secara parsial (individual) dan simultan (keseluruhan) dari variabel bebas (independent) terhadap variabel terikat (dependent). Melalui analisis jalur ini akan ditemukan jalur mana yang paling tepat dan singkat suatu variabel independen menuju variabel dependent yang terakhir dan juga menganalisis hubungan antarvariabel dengan tujuan untuk mengetahui pengaruh langsung maupun tidak langsung seperangkat variabel bebas terhadap variabel terikat yang diolah dengan menggunakan sofware SPSS (stastistical package for sosial scienci) versi 21. Analisis jalur adalah bagian dari model regresi yang dapat digunakan untuk menganalisis hubungan sebab akibat antar satu variabel dengan variabel lainnya. Analisis jalur digunakan dengan menggunakan korelasi, regresi dan jalur sehingga dapat diketahui untuk sampai pada variabel dependen terakhir, harus lewat jalur langsung atau melalui variabel intervening (Sugiyono, 2013:70).

Berdasarkan hipotesis yang diajukan. Maka model analisa jalur dalam penelitian ini dengan rumus ;

$$
\begin{aligned}
& Y_{1}=\rho 1 X_{1}+\rho_{2} X_{2}+e_{1} \ldots \ldots \ldots . . . .(1) \\
& Y_{2}=\rho X_{1} Z X_{1}+\rho X_{2} Z X_{2}+\rho Z Y_{1}+e_{2} \ldots(2)
\end{aligned}
$$

Keterangan:

$\mathrm{Y}_{1}=$ Variabel Motivasi

$\mathrm{Y}_{2}=$ Variabel Kinerja

a $=$ konstanta

$\mathrm{X}_{1}=$ Variabel Kompetensi

$\mathrm{X}_{2}=$ Variabel Lingkungan kerja

$\rho 1=$ Koefisien jalur kompetensi terhadap motivasi

$\rho_{2}=$ Koefisien jalur lingkungan kerja terhadap motivasi

$\rho y_{1}=$ Koefisien jalur motivasi terhadap kinerja

$\rho \mathrm{x}_{1} \mathrm{Y}_{2}=$ Koefisien jalur kompetensi terhadap kinerja

$\rho \mathrm{x}_{2} \mathrm{Y}_{2}=$ Koefisien jalur lingkungan kerja terhadap kinerja

e $=$ Kesalahan

Untuk menguji hipotesis parsial maka dapat dilakukan pengujian yang digunakan adalah uji t dengan rumus sebagai berikut :

$$
\mathrm{t}=\sqrt{\frac{n-(k+1)}{1-r^{2}}}
$$

Dimana :

$\mathrm{n}$ = Jumlah sampel

$r$ = Nilai Korelasi parsial 
$\mathrm{k}=$ Jumlah variabel indepeden

Pengujian uji $\mathrm{t}$ telah dilakukan maka hasil pengujian tersebut $\mathrm{t}$ hitung dibandingkan $\mathrm{t}$ tabel dengan ketentuan sebagai berikut :

a. Jika $t_{\text {hitung }}>t_{\text {tabel }}$ maka $\mathrm{H}_{0}$ ditolak.

b. Jika $\mathrm{t}_{\text {hitung }}<\mathrm{t}_{\text {tabel }}$ maka $\mathrm{H}_{0}$ diterima.

\section{HASIL DAN PEMBAHASAN}

Berdasarkan hasil pengolahan data regresi pada hasil pengolahan diatas, didapatkan hasil pengaruh langsung yang didapatkan melalui proses pengolahan data. Pada analisis jalur, terdapat 2 (dua) jenis pengaruh yang didapat, yaitu pengaruh langsung dan tidak langsung yang kemudian ditotal menjadi pengaruh total keseluruhan variabel terhadap Kinerja Pegawai yang dihasilkan.

\section{Pengaruh Langsung}

Hasil pengaruh langsung penelitian dapat dilihat dari pengujian secara parsial yang dilakukan di tiap struktural penelitian. Pengaruh langsung tiap variabel bebas dihitung dengan rumus:

$$
\text { Pengaruh Langsung Variabel }=\left(\rho \mathrm{x}_{\mathrm{iyi}}\right)^{2}
$$

Hasil dari perhitungan tersebut, didapatkan hasil pengaruh langsung sebagai berikut:

Tabel 2. Pengaruh Langsung

\begin{tabular}{lrr}
\hline \multicolumn{1}{c}{ Variabel } & \multicolumn{1}{c}{ Motivasi } & \multicolumn{1}{c}{ Kinerja } \\
\hline Kompetensi & 0.155 & 0.173 \\
\hline Lingkungan & 0.036 & 0.139 \\
\hline Motivasi & & 0.118
\end{tabular}

\section{Pengaruh Tidak Langsung}

Hasil pengaruh langsung penelitian dapat dilihat dari pengujian secara parsial yang dilakukan di tiap struktural penelitian. Pengaruh tidak langsung tiap variabel bebas dihitung dengan rumus:

$$
\text { Pengaruh Tidak Langsung Variabel }=\mathrm{ry}_{1 \mathrm{Xi}} \mathrm{x} \rho_{\mathrm{y}_{2} \mathrm{Y}_{1} \mathrm{x}} \rho_{\mathrm{y}_{2} \mathrm{xi}}
$$

Hasil pengolahan rumus tersebut didapatkan hasil pengaruh tidak langsung penelitian adalah sebagai berikut:

\begin{tabular}{|c|c|c|c|c|}
\hline Keterangan & $\mathbf{r}_{\mathbf{y} 1 \mathbf{x i}}$ & pY2Y1 & $\rho Y 2 X i$ & Total \\
\hline $\mathbf{X}_{1}$ & 0.480 & 0.344 & 0.416 & 0.069 \\
\hline $\mathbf{X}_{2}$ & 0.367 & 0.344 & 0.373 & 0.047 \\
\hline
\end{tabular}

Tabel 3. Pengaruh Tidak Langsung 


\section{Pengaruh Total}

Hasil pengaruh langsung penelitian dapat dilihat dari total pengaruh langsung dijumlah kan dengan pengaruh tidak langsung yang dilakukan di tiap struktural penelitian. Berikut ini merupakan perhitungan pengaruh total penelitian.

Tabel 4. Pengaruh Total

\begin{tabular}{cccc}
\hline Variabel & $\begin{array}{c}\text { Pengaruh } \\
\text { Langsung }\end{array}$ & $\begin{array}{c}\text { Pengaruh } \\
\text { Tidak } \\
\text { Langsung }\end{array}$ & Total \\
\hline Kompetensi & 0.173 & 0.069 & 0.242 \\
\hline Lingkungan & 0.139 & 0.047 & 0.186 \\
\hline Motivasi & 0.118 & & 0.118 \\
& Total Pengaruh & $\mathbf{0 . 5 4 6}$
\end{tabular}

Berdasarkan perhitungan yang telah dilakukan didapatkan pengaruh total kompetensi, lingkungan kerja, dan motivasi terhadap kinerja didapatkan total pengaruh sebesar 0,546, atau memiliki persentase pengaruh sebesar 54,6\%.

\section{Diagram Jalur Penelitian}

Berdasarkan hasil pada tabel 2 dan 4 maka didapatkan diagram jalur penelitian adalah sebagai berikut:

Gambar 1 Diagram Jalur

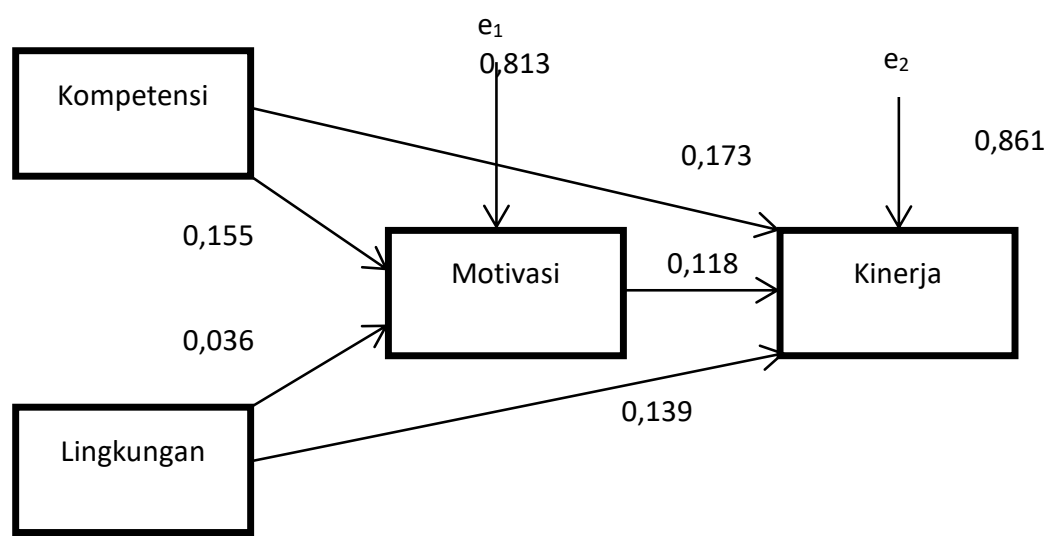

\section{Pembahasan}

Penelitian ini berjudul Pengaruh Kompetensi dan Lingkungan Kerja Terhadap Motivasi Serta Kinerja Pegawai Pada Dinas Tanaman Pangan, Holtikultura dan Perkebunan Provinsi Riau. Tujuan penelitian ini adalah untuk mengetahui pengaruh kompetensi dan lingkungan kerja terhadap motivasi serta kinerja pegawai yang mampu memberikan manfaat bagi instansi terkait serta keilmuan. Sampel penelitian ini adalah 170 pegawai dengan teknik pengambilan sampel menggunakan rumus Slovin yang dikombinasikan dengan Stratified sampling sehingga setiap golongan pegawai mendapatkan peluang yang sama untuk dijadikan penelitian. Teknik analisis data yang digunakan adalah analisis jalur. 


\section{Pengaruh Motivasi Terhadap Kinerja}

Hasil pada penelitian ini menunjukkan bahwa Motivasi berpengaruh terhadap Kinerja. Motivasi merupakan pendorong agar seseorang melakukan suatu kegiatan untuk mencapai tujuannya. Motivasi dalam mempengaruhi kinerja terlihat dari keterkaitan antara indikator setiap variabel. Dapat dilihat dari indikator dimana jika pegawai mendapatkan penghargaan dan pujian atas prestasinya maka akan berupaya untuk lebih baik dalam pencapaian target dan melaksanakan pekerjaan nya secara efektif.

Jika pegawai memiliki tanggung jawab pekerjaan yang jelas dan pekerjaan yang diberikan tersebut memberikan pembelajaran baru bagi pegawai serta menantang, maka pegawai akan terpacu untuk melakukan proses kerja dengan lebih baik dan memberikan ide serta temuan baru dalam bekerja.

Sehingga, semakin tinggi motivasi pegawai akan semakin meningkatkan kinerja yang dapat dicapai oleh pegawai yang sejalan akan menjadikan semakin tingginya kinerja dari instansi terkait.

Hasil dari penelitian ini juga diperkuat dengan penelitian yang dilakukan oleh Joko Waluyo (2014) dan Anidar KH dan Sri Indarti (2015) yang menemukan bahwasanya motivasi berpengaruh terhadap kinerja.

\section{Pengaruh Kompetensi Terhadap Kinerja}

Hasil pada penelitian ini menunjukkan bahwa kompetensi berpengaruh terhadap kinerja. Kompetensi erat kaitanya dengan kinerja dikarenakan kompetensi merupakan kemampuan dari pegawai dalam melaksanakan seluruh tugas yang diberikan. Semakin tinggi kompetensi pegawai dalam melaksanakan tugas, maka kinerja pegawai akan semakin tinggi.

Semakin baik pengetahuan pegawai mengenai bidang tugasnya dan terknik dalam bekerja maka pegawai akan semakin mampu mencapai target pekerjaan secara tepat waktu bahkan pegawai akan mampu memberikan temuan temuan baru dalam bekerja. Pengetahuan yang baik mengenai peraturan perusahaan akan membuat pegawai lebih baik dalam melaksanakan proses bekerja sesuai dengan SOP yang ada dan pegawai akan menjadi lebih disiplin dalam mengikuti seluruh peraturan perusahaan.

Pengetahuan pegawai mengenai sistem informasi dan alat pendukung pekerjaan juga sangat berperan dalam meningkatkan kinerja. Pegawai yang terampil dalam mengoperasikan berbagai sistem dalam pekerjaannya akan mampu untuk menyelesaikan pekerjaan dengan cepat dan cermat.

Hasil dari penelitian ini didukung hasil penelitian yang telah dilakukan sebelumnya oleh Muindi (2015) dan Prabowo (2012), dalam hasil penelitiannya menemukan terdapat pengaruh yang kuat kompetensi terhadap kinerja. Dalam temuan penelitian sebelumnya tersebut ditemukan bahwa kompetensi menjadi andil yang besar dalam meningkatkan kinerja pegawai.

\section{Pengaruh Lingkungan Kerja Terhadap Kinerja}

Hasil pada penelitian ini menunjukkan bahwa Lingkungan kerja berpengaruh terhadap Kinerja. Lingkungan kerja yang dimaksud adalah semua keadaan yang terjadi yang 
berkaitan dengan hubungan kerja, baik hubungan dengan atasan maupun hubungan sesama rekan kerja, ataupun hubungan dengan bawahan.

Lingkungan kerja yang baik tentunya akan membuat rasa aman dan tentram dalam melaksanakan tugas. Hubungan kerja dan komunikasi yang baik antara sesama pegawai maupun antara atasan dan pegawai akan menghadirkan interaksi yang lebih baik sehingga akan muncul keharmonisan dan kekompakan dalam instansi.

Rasa kekeluargaan antara sesama pegawai maupun antar atasan dan pegawai akan membuat pegawai semakin baik dalam membantu satu sama lain dalam melaksanakan proses bekerja. Hubungan komunikasi yang baik, serta kerjasama yang merupakan faktor tingginya kemampuan instansi dalam melaksanakan aktivitas dinas. Oleh karena itu lingkungan kerja merupakan salah satu variabel yang mempu memberikan dampak yang vital bagi pegawai dalam mencapai kinerja yang baik.

Hasil penelitian ini didukung dengan Penelitian tentang pengaruh lingkungan kerja terhadap kinerja sebelumnya yang telah diteliti oleh Maulabakhsh (2015), yang juga menemukan terdapat pengaruh yang besar dari lingkungan kerja terhadap kinerja.

\section{Pengaruh Kompetensi Terhadap Kinerja Melalui Motivasi}

Hasil pada penelitian ini menunjukkan kompetensi melalui variabel motivasi kerja tidak memiliki pengaruh yang kuat terhadap kinerja. Motivasi tidak dapat memediasi pengaruh kompetensi terhadap kinerja.

Rendahnya pengaruh tidak langsung yang diberikan kompetensi melalui motivasi sebagai pemediasi terhadap kinerja disebabkan oleh pengetahuan pegawai mengenai bidang tugas pekerjaan, kemampuan dalam mengorganisir pekerjaa, serta kreatifitas pegawai tidak secara signifikan meningkatkan penghargaan dan pujian dari atasan sehingga kompetensi tersebut tidak mampu memotivasi pegawai dalam meningkatkan kinerja.

Hal lainnya yang menyebabkan pegawai tidak begitu termotivasi adalah karena terdapatnya bidang pengetahuan pegawai yang tidak sesuai dengan pekerjaan sehingga pegawai merasa pekerjaan nya tidak menarik sehingga tidak cukup untuk memotivasi kearah pencapaian kinerja yang lebih baik.

Hasil ini bertolak belakang dengan hasil penelitian yang telah dilakukan oleh Rahim (2017) dimana dalam temuannya menyatakan motivasi dipengaruhi oleh kompetensi, serta oleh Joko Waluyo (2014) yang menemukan motivasi berpengaruh besar terhadap kinerja. Keterkaitan dari penelitian terdahulu tersebut mencerminkan adanya pengaruh kompetensi terhadap kinerja secara tidak langsung, namun penelitian ini tidak menemukan hasil yang sama dengan penelitian yang telah dilakukan sebelumnya.

\section{Pengaruh Lingkungan Kerja Terhadap Kinerja Melalui Motivasi}

Hasil pada penelitian ini menunjukkan lingkungan kerja melalui variabel motivasi kerja tidak memiliki pengaruh terhadap kinerja. Motivasi tidak dapat memediasi pengaruh lingkungan kerja terhadap kinerja.

Rendahnya pengaruh tidak langsung yang diberikan Lingkungan kerja melalui motivasi sebagai pemediasi terhadap kinerja disebabkan oleh hubungan kekeluargaan yang terjalin antar pegawai dan pimpinan tidak mampu meningkatkan secara signifikan 
komunikasi yang lebih baik mengenai tanggung jawab pekerjaan pegawai dan pencapaian tugasnya. Sehingga lingkungan kerja tidak cukup memotivasi pegawai untuk mencapai kinerja yang maksimal.

Hasil ini bertolak belakang dengan hasil penelitian yang telah dilakukan oleh Saeed (2016) dimana dalam temuannya menyatakan motivasi dipengaruhi oleh lingkungan kerja, serta oleh Joko Waluyo (2014) yang menemukan motivasi berpengaruh besar terhadap kinerja. Keterkaitan dari penelitian terdahulu tersebut mencerminkan adanya pengaruh lingkungan terhadap kinerja secara tidak langsung, namun penelitian ini tidak menemukan hasil yang sama dengan penelitian yang telah dilakukan sebelumnya

\section{KESIMPULAN}

Motivasi berpengaruh terhadap kinerja, yang bermakna semakin tinggi motivasi semakin tinggi pula kinerja pegawai. Semakin baik penghargaan dan pujian yang diberikan terhadap capaian kinerja pegawai, maka semakin baik interaksi antar pegawai dan semakin maksimal dalam pencapaian target perusahaan.Kompetensi berpengaruh terhadap kinerja, yang bermakna semakin tinggi kompetensi pegawai semakin tinggi kinerja pegawai. Semakin baik pengetahuan pegawai mengenai bidang tugasnya, peraturan perusahaan, dan teknik dalam bekerja, maka semakin efektif penggunaan waktu dalam bekerja dan semakin baik dalam pencapaian target perusahaan.Lingkungan berpengaruh terhadap kinerja, yang bermakna semakin tinggi lingkungan kerja semakin tinggi pula kinerja pegawai. Semakin baik komunikasi dan rasa kekeluargaan yang terjalin maka semakin baik kerjasama antar pegawai dan semakin baik pegawai dalam melakukan proses bekerja.Kompetensi tidak berpengaruh secara tidak langsung terhadap kinerja melalui motivasi. Artinya motivasi tidak berperan sebagai mediasi antara kompetensi dengan kinerja. Rendahnya kemampuan pegawai dalam melaksanakan pekerjaan sesuai dengan standar operasional prosedur instansi menjadi masalah yang menyebabkan rendahnya pengaruh tidak langsung yang diberikan kepada kinerja melalui motivasi.Lingkungan kerja tidak berpengaruh secara tidak langsung terhadap kinerja pegawai melalui motivasi. Artinya motivasi tidak berperan sebagai medasi antara lingkungan kerja dan kinerja. Hubungan yang erat antara atasan dan pegawai menjadikan suatu faktor yang mempu meningkatkan level dari lingkungan kerja, akibat buruknya hubungan tersebut menjadikan motivasi kerja karyawan rendah, serta kemudian berdampak buruk bagi kinerja pegawai.

\section{DAFTAR PUSTAKA}

Abdillah, Willy dan Jogiyanto. 2015. Partial Least Square (PLS) Alternatif Structural Equation Modeling (SEM) dalam Penelitian Bisnis. Ed.1. Yogyakarta: ANDI

Abdul Raziq, Raheela Maulabakhsh. 2015. Impact of Working Environment on Job Satisfaction. Balochistan University of Information Technology. Pakistan.

Agusta, Leonando dan Eddy Madiono Sutanto. 2013. Pengaruh Pelatihan dan Motivasi Kerja terhadap Kinerja Karyawan (studi kasus pada cv. Haragon Surabaya). Universitas Kristen Petra. Surabaya.

Akdon, dan Riduwan, Rumus dan Data dalam Aplikasi Statistika, Bandung: Alfabeta, 2013 
Anak Agung Ngurah Bagus Dhermawan. 2012. Pengaruh Motivasi, Lingkungan Kerja, Kompetensi, Dan Kompensasi Terhadap Kepuasan Kerja Dan Kinerja Pegawai Di Lingkungan Kantor Dinas Pekerjaan Umum Provinsi Bali. Jurnal Manajemen, Strategi Bisnis, dan Kewirausahaan Vol. 6, 173 No. 2 Agustus 2012.

B. Isyandi. 2018. Manajemen Sumber Daya Manusia Dalam Perspektif Global. Pekanbaru : UNRI Press.

Dwi Agung Nugroho Arianto. 2013. Pengaruh Kedisiplinan, Lingkungan Kerja Dan Budaya Kerja Terhadap Kinerja Tenaga Pengajar. Jurnal Economia, Volume 9, Nomor 2, Oktober 2013.

Florence Muindi dan Professor Peter K'Obonyo . 2015. Quality of Work Life, Personality, Job Satisfaction, Competence, and Job Performance : A Critical Review of Literature. School of Business, University of Nairobi, Kenya.

Faustyna. 2002. Pengaruh Kompetensi dan Komitmen pada tugas terhadap kinerja karyawan pada Hotel Dharma Deli Medan. Universitas Muhammadiyah Sumatera Utara. Medan.

Hutajulu, Togu Charles Edison. 2012. Pengaruh Kompetensi, Komitmen, dan Perubahan Organisasi Terhadap kinerja Pegawai Negeri Sipil di Lingkungan Sekretariat Daerah kabupaten Tapanuli Tengah. Universitas Terbuka. Jakarta.

Leblebici, Demet. 2012. Impact of Workplace Quality on Employees Productivity : Case Study of a Bank in Turkey. ournal of bussiness, Economics \& Finance ISSN: 2146-7943.

Mangkunegara, Anwar Prabu. 2013, Manajemen Sumber Daya Manusia Perusahaan, Remaja Rosdakarya, Bandung.

M Anang Firmansyah. 2018. Pengaruh Faktor-Faktor Lingkungan Kerja Internal Dan Pekerjaan Terhadap Motivasi Kerja Karyawan Pada Pt. Warnatama Cemerlang Gresik. Balance Vol. XV No. 2 Juli 2018.

Mathis L. Robert dan John H. Jackson. 2012. Manajemen Sumber Daya Manusia. Alih Bahasa. Jakarta : Salemba Empat. Edisi 10.

Meutia, Ika Sari dan Tubagus Ismail. 2014. Pengaruh Kompensasi Dan Kompentesi Dengan Motivasi Sebagai Intervening Dalam Meningkatkan Kinerja. Jurnal Manajemen Volume XX, No. 03, Oktober 2016: 353-369.

Nitisemito, Alex S. 2010. Manajemen personalia Manajemen Sumber Daya Manusia. Edisi Ketiga. Jakarta : Ghalia Indonesia

Nugroho, Agung. 2012. Pengaruh Motivasi, Lingkungan kerja, Kompetensi dan Kompensasi terhadap kepuasan kerja dan kinerja pegawai dilingkungan kantor Dinas pekerjaan Umum Prov. Bali. Fakultas Ekonomi Universitas Udayana. Bali.

Parveen, Sajida, dkk. 2012. Impact of Office Facilities and Workplace Milieu on Employee's Performance : A Case Study of Sarghoda University. Asian Journal of Empirical Research, 2(4): 96-117. Pakistan. 
Pendow, Jessica dan Peggy A Mekel. 2015. Pengaruh Perekrutan, Motivasi, dan Pelatihan Kerja Terhadap Kinerja Karyawan PT. PLN (persero) Wilayah Suluttenggo. Universitas Sam Ratulangi. Manado.

Prabowo, Ady Satya. 2012. Pengaruh kemampuan dan motivasi terhadap kinerja karyawan Akuntansi pada kantor konsultan pajak. STIE Widya Manggala. Semarang.

Putra, Chairuddin Surya, Harlen dan Machasin. 2014. Pengaruh Kepemimpinan, Motivasi Dan Budaya Organisasi Terhadap Kinerja Pegawai Pada Badan Perencanaan Pembangunan Daerah (Bappeda) Kota Dumai. Jurnal Ekonomi Volume 22, Nomor 3 September 2014.

Purwantoro, P., \& Afrizal, A. (2019, August). Evaluation of items on instruments of consumer attitudes, word of mouth, and decisions of private universities. In Journal of Physics: Conference Series (Vol. 1255, No. 1, p. 012092). IOP Publishing.

Rahim. Abdul. 2017. Pengaruh Lingkungan Kerja Dan Kompetensi Terhadap Motivasi Kerja Serta Dampaknya Terhadap Kinerja Pegawai Pada Dinas Pendidikan Kabupaten Tanjung Jabung Timur. J-MAS Vol.2 No.2, Oktober 2017.

Safwan , dkk. 2014. Pengaruh Kompetensi dan Motivasi terhadap Kinerja Pengelolaan Keuangan Daerah pada Pemerintah Daerah Kabupaten Pidie Jaya. Universitas Syiah Kuala. Banda Aceh.

Sanjaya, I Kadek Edy dan Ayu Desi Indrawati. Pengaruh Kompetensi, Kompensasi, dan Lingkungan Kerja terhadap Kinerja Karyawan pada PT. Pande Agung Sedara Dewata. Universitas Udayana (UNUD). Bali.

Setiawan, Budi. 2014. Pengaruh Kompetensi dan Motivasi terhadap Kinerja Pegawai Negeri Sipil di Lingkungan Badan Penanaman Modal dan Pelayanan Terpadu Satu Pintu (BPMPTSP) Privinsi Kalimantan Barat. Vol 1, No 1 Jurnal Manajemen dan Bisnis Universitas. Tanjungpura.

Shimko, Yulniwarti. 2012. Pengaruh gaya Kepemimpinan, Motivasi, dan Lingkungan kerja terhadap Kinerja Pegawai Negeri Sipil pada kantor pemerintahan kabupaten Solok Selatan, Sumatera Barat. Institut Bisnis dan Multimedia asmi.

Shahzadi, Irum, dkk. Impact of Employee Motivation on Employee Performance. The Islamia University of Bahawalpur. Pakistan.

Sedarmayanti. 2011. Manajemen Sumber Daya Manusia, Birokrasi, dan Manajemen Pegawai Negeri Sipil. Bandung: PT. Refika Aditama.

Sudarmanto. 2009. Kinerja dan Pengembangan Kompetensi SDM. Yogyakarta: Pustaka Pelajar.

Umam, Khaerul. 2010. Perilaku Organisasi. Bandung: Pustaka Setia.

Wibowo. 2014. Manajemen Kinerja. Jakarta: Rajawali Pers.

Wirawan. 2011. Budaya dan iklim organisasi: teori aplikasi dan penelitian. Jakarta: Salemba Empat. 